\title{
Light alcohol drinking and the risk of developing cancer, a systematic review.
}

Davide Ciardiello ( $\sim$ davideciardiello@yahoo.it)

Universita degli Studi della Campania Luigi Vanvitelli https://orcid.org/0000-0003-1826-0305

Giuseppe Gerardo Caprio

Universita degli Studi della Campania Luigi Vanvitelli

Desiree Picascia

Universita degli Studi della Campania Luigi Vanvitelli

Marcello Dallio

Universita degli Studi della Campania Luigi Vanvitelli

PietroPaolo Vitiello

Universita degli Studi della Campania Luigi Vanvitelli

Emilio Francesco Giunta

Universita degli Studi della Campania Luigi Vanvitelli

Vincenzo De Falco

Universita degli Studi della Campania Luigi Vanvitelli

Vincenzo Famiglietti

Universita degli Studi della Campania Luigi Vanvitelli

Erika Martinelli

Universita degli Studi della Campania Luigi Vanvitelli

Antonietta Gravina

Universita degli Studi della Campania Luigi Vanvitelli

Alessandro Federico

Universita degli Studi della Campania Luigi Vanvitelli

Fortunato Ciardiello

Universita degli Studi della Campania Luigi Vanvitelli

Carmelina Loguercio

Universita degli Studi della Campania Luigi Vanvitelli

\section{Research article}

Keywords: alcohol, cancer, meta-analysis

Posted Date: November 1st, 2019

DOI: https://doi.org/10.21203/rs.2.16717/v1

License: (c) This work is licensed under a Creative Commons Attribution 4.0 International License. Read Full License 


\section{Abstract}

Background: There is strong evidence that heavy alcohol consumption ( $>50 \mathrm{~g}$ per day) is a risk factor for several disease, including cancer. However, the oncogenic role of light alcohol drinking $(<12,5 \mathrm{~g}$ per day) is still controversial. The purpose of this review is to assess whether the intake of a single daily dose of alcohol could determine an increased risk of malignancy onset.

Methods: A systemic PubMed research of meta-analysis studies, using the keywords "light alcohol drinking", "light alcohol consumption" and "cancer", was done. We established a period of 15 years, in order to select the most recent evidences; exclusively meta-analysis that specified levels of alcohol intake were included in the review. Studies focused on biochemical, molecular and genetic aspects, as well as duplicate articles were excluded.

Results: We included in this review 29 large meta-analysis; light alcohol drinking was not associated with an increased risk of occurrence of most cancers, with the exception of breast, prostate cancer and, with less evidence, melanoma. Furthermore, a protective role of alcohol assumption on the development of bladder, kidney ovarian cancer and Non Hodgkin Lymphoma (NHL), has been described.

Conclusions: We found that light alcohol drinking do not determine a higher risk for the insurgence of several malignancies, except for a light increase in the incidence of melanoma, breast cancer in women and prostate cancer in men.

\section{Background}

Alcohol consumption is recognised as a causal factor for several health problems and is actually the world third largest risk factor for disease and disability worldwide (1).It is strictly correlated with cardiovascular disease, cirrhosis of the liver, epilepsy, road accidents and several malignancies. In 2012 the International Agency for Research on Cancer (IARC) showed a strong relationship between alcohol consumption and carcinogenesis, estimating that $5.5 \%$ of all new cancer occurrences and $5.8 \%$ of all cancer deaths worldwide were related to alcohol drinking (2).

Alcohol consumption has been associated with cancers of oral cavity and pharynx, oesophagus, larynx, liver, stomach, pancreas, colon, rectum, breast and prostate (3-10). Based on this evidence alcohol is classified as Group 1 carcinogen by IARC (2). In 2015, European Code Against Cancer (ECAC) fourth edition on alcohol drinking and cancer recommends "If you drink alcohol of any type, limit your drinking. Not drinking is better for cancer prevention." (11). While there is a strong correlation between heavy ( $>50 \mathrm{~g}$ per day) and moderate alcohol drinking ( $>12,5 \mathrm{~g}$ and $<50 \mathrm{~g}$ per day) and cancer, data regarding the carcinogenic role of light alcohol drinking ( $<12,5 \mathrm{~g}$ per day) are still controversial (12). In this review we would like to clarify if even the assumption of a single daily dose of alcohol, like a glass of wine, could determinate an increase of the relative risk of malignancy onset.

\section{Methods}

A systematic literature review of meta-analysis was conducted in order to evaluate the association between light alcohol drinking and risk of cancer. We searched PubMed using keywords "light alcohol drinking," "light alcohol intake," "light alcohol consumption," and "cancer," using "meta-analysis". We chose to establish a period of 15 years (from 2004 to 2019), in order to analyse the most recent evidences, which generated 29 studies (included in table 1). We used the following criteria for inclusion: meta-analysis studying the relationship between alcohol consumption and the risk of cancer published in English, focusing on the amount of alcohol intakes and evaluating the effects of low doses of alcohol. Publications only dealing with biochemical, molecular and genetic aspects, as well as duplicate articles were excluded.

\section{Results}

\section{Alcohol consumption and the risk of cancer of non-Hodgkin lymphoma (NHL)}

Two meta-analysis were identified evaluating the association between $\mathrm{NHL}$ and alcohol consumption $(13,14)$. The first study found a $15 \%$ reduction of NHL risk in current alcohol drinkers compared with non-drinkers (relative risk RR 0,85, 95\% $\mathrm{Cl} 0,79-0,91$ ), regardless of the amount of consumption [light: (RR 0,88, 95\% Cl 0,81-0,96); moderate: ( $R R$ finding significant differences across strata of sex, type of controls and the two main subtypes of NHL (i.e. T-cells versus B-cell lymphoma) (13). The second metanalysis reported a favourable role of alcohol drinking on NHL risk, both on ever and current drinkers (RR 0,89 $95 \% \mathrm{Cl}$ 0,83-0,95). Interestingly, it was found a significant difference on the type of alcoholic beverage and on sex gender; only ever/current consumption of beer was associated with a reduced risk of NHL (RR 0,88 95\% Cl 0,81-0,95) compared to wine and liquor (respectively RR $0,9695 \% \mathrm{Cl} 0,9-1,12 ; \mathrm{RR} \mathrm{0,9} 95 \% \mathrm{Cl}$ 0,79-1,02), whereas the protective effect of alcohol drinking was demonstrated only in male subjects 
(RR 0,88 95\% Cl 0,78-0,98) (14). Finally, regarding the histological subtype of NHL, an inverse correlation between alcohol intake and NHL was proved in diffuse large B-cell lymphoma and follicular lymphoma $(13,14)$.

\section{Alcohol consumption and the risk of cancer of oesophageal cancer (OSCC)}

Islamini and colleagues conducted a meta-analysis of 40 case-control studies and 12 cohort studies, showing a link between light, moderate and high alcohol drinking and the risk of OSCC (RR: 1.31 Cl 95\% 1.10-1.57; RR: $2.27 \mathrm{Cl} 95 \%$ 1.89-2.72; RR: 4.89 Cl 95\% 3.846.23); however, the increased risk in light alcohol drinkers was limited to the Asian population (RR, 1.63; $95 \% \mathrm{Cl}, 1.20-2.22)(15)$. These associations were also evidenced among never-smokers (RR, $0.7495 \% \mathrm{Cl}$ 0.47-1.16 for light, 1.54; $95 \% \mathrm{Cl}, 1.09-2.17$ for moderate, and $\mathrm{RR}, 3.09 ; 95 \% \mathrm{Cl}, 1.75-5.46$ for high intakes) (15). A second meta-analysis including 24 studies in 2012 reported no significant correlation between both oesophageal and gastric cardia adenocarcinoma risk and light (0.86; $95 \% \mathrm{Cl} 0.75-0.99)$, moderate $(0.9095 \% \mathrm{Cl} 0.73-$ $1.10)$ and heavy $(1.16 ; 95 \% \mathrm{Cl} 0.92-1.46)$ alcohol consumption (16).

\section{Alcohol consumption and the risk of gastric cancer}

A first meta-analysis showed no association between alcohol ingestion and gastric cancer for light and moderate alcohol assumption (RR: 0.95; 95\% Cl: 0.88-1.02; RR: 1.05; 95\% Cl: 0.98-1.13, respectively).Nevertheless,a significant increase in relative risk of development of gastric cancer in case of heavy consumption, was reported (RR: 1.13; 95\% Cl: 1.06-1.21).Interestingly, a lower risk of gastric cancer in women consuming low doses of alcohol, was found (RR: $0.74 ; 95 \% \mathrm{Cl}$ : $0.57-0.98$. (17). A second meta-analysis by Rota and colleagues, reported an increase in the risk of developing gastric cancer in case of consumption of 4 to 6 drinks/day (RR: $1.2695 \% \mathrm{Cl}, 1.08-1.48)$ and $>6$ drinks/day (RR: $1.4895 \% \mathrm{Cl} 1.29-1.70$ ), especially in never smoking subjects (RR 1.87, 95\% Cl 1.35-2.58). There was no significant correlation under that threshold ( $\leq 1$ drink/day: RR $1.0095 \% \mathrm{Cl} 0.86-1.16)(18)$.

\section{Alcohol consumption and the risk of pancreatic cancer}

Two studies were selected evaluating the role of alcohol intakes in the onset of pancreatic cancer $(19,20)$. The first meta-analysis conducted by Wang and colleagues, concluded that only high level of consumption determined an increased risk of developing pancreatic cancer (RR, 1.15; $95 \% \mathrm{Cl}: 1.06-1.25)$. The risk was higher in male gender (RR 1.18; $95 \% \mathrm{Cl}: 1.00-1.39$ ) and in case of liquor consumption (RR, 1.66; $95 \%$ Cl: 1.24-2.23) (19). A second study by Tramacere and colleagues, collecting 21 case control and 11 cohort studies, reported a $20 \%$ increase in the risk of pancreatic cancer among heavy alcohol drinkers (defined as 3 or more drinks/day), compared with non-or occasional drinkers, with a relative risk of $1.22(95 \% \mathrm{Cl}, 1.12-1.34)$. Furthermore, no significant increase in cancer risk in case of drinking less than 3 drinks/day was found (RR:0.92 95\% Cl, 0.86-0.97) (20).

\section{Alcohol consumption and the risk of colon cancer}

We selected four meta-analysis assessing the link between alcohol intakes and the overall risk of colorectal cancer (21-24). The first study, including 4687 cases of colorectal cancer, suggested an increased risk limited to alcohol intake of 30-45 g/day (RR: 1.21 Cl 95\% 1.041.42), and $>45 \mathrm{~g} /$ day (RR: $1.51 \mathrm{Cl} 95 \% 1.25-1.83$ ), but no significant correlation for consumption $<30 \mathrm{~g} /$ day, and no significant differences among sex gender, type of alcohol beverage and tumor site (21). Fedirko and colleagues showed that drinkers of 12.6-49.9 g/day and more than $\geq 50 \mathrm{~g} /$ day of alcohol had respectively a $21 \%$ and $52 \%$ increased risk for colorectal cancer (RR: $1.2195 \% \mathrm{Cl} 1.13-1.28$ and 1.52 $95 \% \mathrm{Cl} 1.27-1.81$ ), whereas light alcohol consumption ( $\leq 12.5 \mathrm{~g} /$ day of ethanol) was not associated with an increased risk (RR: $1.0095 \%$ $\mathrm{Cl} 0.95-1.05)$. However, they found a slightly statistically significant $7 \%$ increase in the incidence of colorectal cancer risk for $10 \mathrm{~g} / \mathrm{day}$ of alcohol intake at the dose-risk analysis; authors also highlighted an increase of overall risk in male moderate drinkers $(\mathrm{RR}=1.24,95 \% \mathrm{Cl}$ 1.13-1.37) and in Asiatic heavy drinkers ( $\mathrm{RR}=1.81,95 \% \mathrm{Cl} 1.33-2.46)(22)$.

Another meta-analysis published by Mizoue and colleagues evidenced a strong correlation linking alcohol intakes and colon cancer in case of consumption of more than $23 \mathrm{~g} /$ day, while finding no correlation $<23 \mathrm{~g} /$ day in men (RR: $1.22 \mathrm{Cl} 95 \%$ 0.92, 1.61), neither in women (RR: $0.93 \mathrm{Cl} 95 \% 0.70,1.23)(23)$. Finally, the meta-analysis by Wang and colleagues, including 22 case-control and only 2 cohort studies, described a dose-response and a positive correlation in case of any amount of alcohol drinking, even in case of less than 12,5 g/day of ethanol (overall pooled RR: $1.0795 \% \mathrm{Cl}, 1.02-1.13$ ); however, by stratifying the results by study types, the increased risk was found only in case-control studies ( $R R=1.08, \mathrm{Cl} 95 \% 1.02-1.14)$ and not in cohort studies ( $R R=1.02, \mathrm{Cl} 95 \%$ 0.85-1.21)(24).

\section{Alcohol consumption and the risk of brain tumours}

One meta-analysis, including 13 case-control and 6 cohort studies, evidenced no association between alcohol and brain tumours (26). However, the authors reported a $20 \%$ increase in risk for spirit consumption (RR 1.20 95\% Cl 1.01-1.42; P 0.584). 
A first meta-analysis including 16 studies (14 case control and 2 cohort investigations), evidenced alcohol drinking as a risk factor for CM; the overall pooled RR was 1.20 (95\% Cl 1.06-1.37; P=0.006), similar between case-control (RR 1.20, 95\% Cl 1.01-1.44; Po.041) and cohort studies (RR1.26, 95\% Cl 1.19-1.35; P<0.001) (26).

The pooled RR estimates for the correlation between light alcohol drinking and CM were 1.10 (95\% Cl 0.90-1.26) overall, 1.06 (95\% Cl 0.90 1-25) among case-control studies and 1.25 (95\% Cl 1.15-1.35) among cohort studies. For moderate-heavy alcohol drinking vs no drinking, the pooled RR were $1.18(95 \% \mathrm{Cl} 1.01-1.40)$ overall, $1.13(95 \% \mathrm{Cl} 0.9-141)$ among case-control studies and $1.29(95 \% \mathrm{Cl} 1.17-1.43)$ among cohort studies. However, no significant association was found in the pooled RR from 10 studies adjusted for sun exposure (RR1.12, Cl 95\% 0.86-1.45). Another meta-analysis found a moderate association with melanoma risk (27). The summary relative risk (SRR) was 1.29 (95\% $\mathrm{Cl} 1.14-1.45 \mathrm{I} 2=13 \%)$ for those in the highest vs. lowest category of current alcohol intake and $1.96(95 \% \mathrm{Cl} 1.02-3.76, \mathrm{I}=0)$ for cumulative intake. Moreover, in the dose response analysis, the increase in risk associated with a $10 \mathrm{~g}$ increment in daily alcohol intake was 1.07 (95\% Cl 1.03-1.11, 12=50\%).

\section{Alcohol consumption and the risk of lung cancer}

A study by Bagnardi and colleagues showed no association between lung cancer and alcohol drinking in never smokers (RR $1.2195 \% \mathrm{Cl}$ : 0.95-1.55) (28). Moreover, at the dose-response analysis, RR for an increase in alcohol intake of $10 \mathrm{~g} /$ day was 1.01 (95\% Cl: 0.92-1.10) (28).

A second meta-analysis based on 10 studies, demonstrated a decrease in risk of lung cancer for light alcohol drinking (RR 0.91 95\%Cl: $0.90-$ 0.94 I2=0) (29).

\section{Alcohol consumption and the risk of laryngeal cancer}

Regarding the correlation between alcohol consumption and the risk of laryngeal cancer, Islamini and colleagues showed a 2-fold increase in risk of laryngeal cancer for drinkers vs non-drinkers (RR $1.9095 \% \mathrm{Cl}: 1.59-2.28 \mathrm{p}<0.001)(30)$. While light alcohol drinking was not linked with the risk of developing laryngeal cancer (RR0.88 95\% Cl: 0.71-1.08), moderate alcohol drinking (RR 1.47, 95\% Cl: 1.25-1.72) and heavy alcohol drinking (RR 2.62, 95\% Cl: 2.13-3.23) determined respectively a 1.5 and 2.5-fold increase compared to non-/occasional drinking (30).

\section{Alcohol consumption and the risk of oral and pharyngeal cancer}

A meta-analysis of Bagnardi and colleagues showed an increased risk of developing oral and pharyngeal cancer with a $\mathrm{RR}$ of $1.13(95 \% \mathrm{Cl}$, 1.00-1.26) for light, RR 1.83 ( $95 \%$ Cl, 1.62-2.07) for moderate and RR 5.13 ( $95 \% \mathrm{Cl}, 4.31-6.10)$ for heavy alcohol drinking (12). However, for light alcohol consumption, no increase in tumorigenic risk was found in cohort studies (RR $0.8695 \% \mathrm{Cl}, 0.60-1.23$ ). Moreover, light alcohol intake determined an increase in the risk only in the Asian population (RR $1.3395 \% \mathrm{Cl}, 1.06-1.68$ ), in contrast with European (RR 0.95, 95\% $\mathrm{Cl}$ 0.80-1.12) and North American population (RR $1.0995 \% \mathrm{Cl}, 0.92-1.29$ ).

\section{Alcohol consumption and the risk of breast cancer}

A first meta-analysis evidenced a higher risk of breast cancer with increasing consumption of alcoholic beverages; in comparison with nondrinkers, women that assume $12 \mathrm{~g} /$ day of alcohol had a relative risk of 1.10 (95\% Cl: 1.06-1.14).Moreover, no significant difference was found regarding the state of menopause or the type of drink consumed (31). Suzuki et colleagues evidenced a positive relationship between alcohol drinking and development of breast cancer. Authors reported that consumption of more than $10 \mathrm{~g}$ of ethanol per day determined a $12 \%$ increase in the occurrence of oestrogen receptor positive breast cancer and $7 \%$ increase for oestrogen receptor negative tumours (32).

\section{Alcohol consumption and the risk of ovarian cancer}

A first meta-analysis by Kelemen and colleagues, evidenced that alcohol intake was not associated with risk of ovarian carcinoma (consumption of $>3$ drinks per day compared to none: $\mathrm{OR}=0.92,95 \% \mathrm{Cl}=0.76-1.10, \mathrm{P}$ trend $=0.27$ ) (33).

Another meta-analysis showed no effects of alcohol consumption on the incidence of ovarian cancer in drinkers vs non-drinkers (RR 1.03 $95 \% \mathrm{Cl} 0.96-1.10)$. Furthermore, low (RR $1.0295 \% \mathrm{Cl} 0.94-1.11$ ), moderate (RR 1.08, 95\% Cl 0.92-1.27) and heavy alcohol consumption (RR $0.99,95 \% \mathrm{Cl} 0.88-1.12$ ) showed no significant effects on the risk of this neoplasm. Finally, authors also noticed a protective effect of low doses of alcohol on ovarian cancer incidence when the participants were from outside US (34).

\section{Alcohol consumption and the risk of prostatic cancer}

A recent meta-analysis by Rota and colleagues reported an association between alcohol consumption and prostate cancer (35). 
Interestingly, the authors noticed an overall RR of $1.06(95 \% \mathrm{Cl}, 1.01-1.10)$ for any alcohol drinking compared with non/occasional drinking. Furthermore, the dose-risk analysis showed borderline statistically significant RRs of 1.05 (95\% Cl, 1.02-1.09) for light alcohol drinking (</= 1 drink/ day) and $1.06(95 \% \mathrm{Cl}, 1.01-1.11)$ for moderate drinking ( $>1$ to $<4$ drinks/day). Finally, they found a non-significant association at high levels of alcohol drinking (>/=4 drinks/day), with a pooled RR of $1.08(95 \% \mathrm{Cl}, 0.97-1.20)(35)$.

Another meta-analysis reported a statistically significant dose-response relationship between alcohol consumption and risk of prostate cancer starting with<25 g ethanol / day (RR 1.08, 95\% Cl 1.04-1.11) (36). Medium (25-<45 g/day), high (45-<65 g / day) and higher volume drinkers (65+ g / day) had a significantly enhanced risk [RR1.07 (95\% Cl 1.02-1.12), 1.14 (95\% Cl 1.08-1.22) and 1.18 (95\% Cl 1.10-1.27) respectively]. The increase in incidence observed for low-volume drinkers was relatively small in the aggregate analysis (8\%), but was $23 \%$ in studies without erroneous classification errors (for example, the common practice of considering drinkers like abstainers).

\section{Alcohol consumption and the risk of bladder cancer}

A large meta-analysis by Mao and colleagues, including 19 studies (both case-control studies and cohort studies) reported no significant association between alcohol drinking and bladder cancer (OR = 1.00, 95\% $\mathrm{Cl} 0.89-1.10)(37)$. The authors also found a negative relation between beer and wine consumption and the probability of bladder cancer.

Another more recent meta-analysis confirmed the findings from meta-analysis of Mao and colleagues (38). The pooled RRs for $<3$ drinks per day, were 1.00 (95\% Cl 0.92-1.09), specifically 1.07 (95\% Cl 0.85-1.36) among cohort and 0.99 (95\% Cl 0.89-1.09) among case-control studies. All the data on heavy drinkers were from case-control studies ( $\mathrm{RR}=1.02,95 \% \mathrm{Cl} 0.78-1.33$ ). Results were consistent in several subgroup analyses, including those of studies adjusted for smoking (38).

\section{Alcohol intake and risk of renal cell carcinoma (RCC)}

A first meta-analysis observed an inverse association between alcohol intake and risk of RCC, when comparing the highest versus the lowest alcohol consumption categories, with a statistically significant $30 \%$ reduction in incidence of RCC (RR 0.70, 95\% CI 0.60-0.81) (39). Remarkably, alcohol consumption of $12 \mathrm{~g}$ ethanol per day was correlated with a $5 \%$ reduction in the risk of RCC (OR 0,67, $95 \% \mathrm{Cl} 0,62-0,73)$.

Another meta-analysis confirmed an inverse relationship between alcohol intake and risk of RCC (RR 0.73, 95\% Cl 0.67-0.79) (40). Interestingly, the inverse association was stronger for cohort studies (RR 0.71, 05\% $\mathrm{Cl} 0.63-0.78$ ) than for case-control studies (RR $0.76,95 \%$ $\mathrm{Cl}$ 0.68-0.85) (40). However, the authors highlighted that consumption up to $15 \mathrm{~g}$ per day of ethanol, could lead to a decrease in the risk of RCC, but additional consumption does not confer further benefits in the prevention of RCC.

Finally, a third meta-analysis, reported a negative link between alcohol consumption and risk of RCC, significant for both light (<12, 49 $\mathrm{g} /$ day) and moderate (12.5-49.9 g/day), but not for heavy drinking ( $\geq 50 \mathrm{~g} /$ day) [RR: 0.90 (95\% Cl: 0.84-0.97), 0.79 (95\% Cl:0.71-0.88) and 0.98 (95\% Cl 0.58-1.39), respectively) (41).

\section{Discussion}

Collectively the current analysis evidences that light alcohol drinking does not increase the risk of developing most of cancer, with the exception of breast cancer, prostate cancer and, with less evidence, melanoma.Furthermore, a protective effect of alcohol assumption on the occurence of bladder, kidney,cancer and NHL, has been described. The role of light alcohol drinking as a causal factor for the insurgence of malignancies is still debated (11). A meta-analysis by Bagnardi and colleagues, showed an increased risk of oral cavity, pharynx, oesophagus and female breast cancer even for light alcohol drinking (42). However, as already suported by Myung in his letter to Annals of Oncology, this assumption was principally derived by the analysis of case-control studies, which are more susceptible to recall, or selection bias compared to cohort studies (43). Furthermore, Myung stated that a significant statistical increase in risk of cancers for light alcohol drinkers was confirmed exclusively in breast cancer, while it does not reach a significance for the other tumors (43).

Recently, Griswold and colleagues published a large systemic meta-analysis of the correlation between alcohol consumption and global disease burden; the authors concluded: "the level of consumption that minimizes health loss is zero" (44). However, the study had several limitations and does not take in account key issues, like environmental factors, genetic differences among the various ethnic groups included in the analysis, together with possible underestimation bias.

Surely, even though mechanisms underlying alcohol-related carcinogenesis are not completely elucidated, different studies showed that chronic alcohol consumption, especially for high doses, could cause the onset of cancers (45-47).

The mechanisms of alcohol on tumorigenesis include the production of acetaldehyde (derived from ethanol metabolism), oxidative stress, effects on metabolism, endocrine and immunity system, together with the influence of genetic polymorphisms regulating the absorption and the metabolic pathway of this substance (45-47). A multitude of genes contribute to the correct metabolism of alcohol, like those for

Page 5/18 
$\mathrm{ADH}, \mathrm{ADLH}, \mathrm{CYP} 2 \mathrm{E} 1$, and methylene-tetrahydrofolate reductase (MTHFR). The presence of some polymorphisms in these genes could reduce the elimination of acetaldehyde and favour the development of malignancies. In fact, carriers of $A L D H 2 * 1 / * 2$ or $A L D H 2 * 2 / * 2$ genotypes of the ALDH2 gene, compared to $A L D H 2 * 1 /{ }^{*}$,exhibit a reduced enzymatic activity, leading to an increased accumulation of acetaldehyde (48).

This polymorphism is predominant in the Asian population and could be responsible of the higher risk of upper digestive cancers in moderate and heavy drinkers in that area (49). However, some bias could influence these results. Regarding this point, a recent study of Cao and colleagues, demonstrated that alcohol intakes $\geq 30 \mathrm{~g} /$ day were strongly associated with risk of total cancer only among male ever smokers, while for women, even an alcohol consumption of 5-14.9 g/day could increase that risk, but this result was found to be mainly driven by breast cancer (50).

Alcohol is also responsible for changes in hormonal balance and metabolism (51). In this respect, we observed a link between breast cancer and light alcohol drinking; these results are consistent with literature evidence. Chen and colleagues carried out a large prospective cohort study concluding that even a consumption as low as 5.0-9.9 gm/day could determine an increased breast cancer risk, independently from the type of beverages (52).

The association between alcohol drinking and breast cancer can be explained by the increase of circulating oestrogens (caused by a decrease in aromatase activity). Moreover, recent studies in vitro and in vivo suggest that alcohol could promote cancer growth through epigenetic regulation of gene expression in the breast tissue, beside enhancing its progression by stimulating epithelial-mesenchymal transition (53).

We also found a correlation between light alcohol drinking and increased risk of prostatic adenocarcinoma, in agreement with a recent study (54). The biological mechanisms by which ethanol intake could increase the risk of prostate cancer are not completely understood. Acetaldehyde could have a genotoxic effect, promote induction of microsomal cytochrome P450 2E1 (CYP2E1), increase oxidative stress, augment oestrogen concentration, act as a solvent for tobacco carcinogens, determine changes in metabolism of folates and DNA repair (54).

New evidences suggest a possible link between alcohol and an increased risk of CM. In fact, acetaldehyde could act as a photosensitizing agent causing an enhanced susceptibility to UV-mediated cell damage $(26,27)$.

In our study, we found out that light drinking could be a protective factor for renal cell carcinoma, bladder cancer and, with less evidence, for $\mathrm{LNH}$. Concerning the two genitourinary malignancies, the protective role of alcohol could be explained by the presence of other compounds in alcoholic beverages (xanthohumol and resveratrole), by enhancing insulin sensitivity and/or to its diuretic effect, responsible for a higher frequency of bladder emptying and a consequent lower exposure of the carcinogens to the bladder epithelium(56-59). Less clear is the decrease of incidence of NHL in light drinkers; it could be related, according to Psaltopoulou and colleagues, to a reduced activation of mammalian targetof rapamycin (mTOR) complex, capable of inducing autophagy in cell lines of NHL; other possible mechanisms includes immune-modulating effect of ethanol, the antioxidant effect, improved insulin sensitivity(58-60).

\section{Conclusions}

In conclusion, the current study highlights how the intake of low alcohol doses does not correlate with an increase in the incidence of different types of cancer, with the exception of breast cancer in women, and prostate cancer in men. On the other hand, alcohol drinking could even have a protective effect, as in the case of kidney cancer, bladder cancer, and the NHL.

Although new evidence suggests that abstention from alcoholic beverages is the only way to prevent various diseases, the correlation with tumorigenesis for low doses of alcohol drinking (like the daily consumption of a glass wine), is still unclear and has to be confirmed by modern large cohort studies.

\section{Abbreviations}

NHL: Non Hodgkin Lymphoma; IARC: International Agency for Research on Cancer; ECAC: European Code Against Cancer; RR: Relative Risk; OSCC: Oesophageal cancer; CM: cutaneous melanoma; RCC: renal cell carcinoma; MTHFR: methylene-tetrahydrofolate reductase;

\section{Declarations}

\section{Ethics approval and consent to participate}


Not Applicable.

\section{Consent for publication}

Not Applicable.

\section{Competing interests}

The authors have no conflict of interest to declare.

\section{Acknowledgments}

Not Applicable.

\section{Funding}

No funding was obtained for the review.

\section{Contributions}

GC, DP, DC, CL and FC have made significant contribution to the conception of the study. MD, PPV, AGG, FA, EFG, VDF, VF AND EM were involved in data analysis. GC, DP, DC and CL have drafted the manuscript and substantially revised it. All authors read and approved the final manuscript.

\section{Correspondence: davideciardiello@yahoo.it}

\section{References}

1. World Health Organization. Global status report on alcohol and health. Geneva: World Health Organization; 2014

2. ARC Working Group on the Evaluation of Carcinogenic Risks to Humans. Personal habits and indoor combustions. Volume 100 E. A review of human carcinogens. IARC Monogr Eval Carcinog Risks Hum. 2012;100(Pt E):1-538.

3. Li Y, Mao Y, Zhang Y, Cai S, Chen G, Ding Y, Guo J, Chen K, Jin M. Alcohol drinking and upper aerodigestive tract cancer mortality: a systematic review and meta-analysis. Oral Oncol. 2014 Apr;50(4):269-75. doi: 10.1016/j.oraloncology.2013.12.015

4. Islami F, Tramacere I, Rota M, Bagnardi V, Fedirko V, Scotti L, Garavello W, Jenab M, Corrao G, Straif K, Negri E, Boffetta P, La Vecchia C. Alcohol drinking and laryngeal cancer: overall and dose-risk relation-a systematic review and meta-analysis. Oral Oncol. 2010 Nov;46(11):802-10. doi: 10.1016/j.oraloncology.2010.07.015.

5. Turati F, Galeone C, Rota M, Pelucchi C, Negri E, Bagnardi V, Corrao G, Boffetta P, La Vecchia C. Alcohol and liver cancer: a systematic review and meta-analysis of prospective studies. Ann Oncol. 2014 Aug;25(8):1526-35. doi: 10.1093/annonc/mdu020

6. Tramacere I, Negri E, Pelucchi C, Bagnardi V, Rota M, Scotti L, Islami F, Corrao G, La Vecchia C, Boffetta P. A meta-analysis on alcoholdrinking and gastriccancerrisk. Ann Oncol. 2012 Jan;23(1):28-36. doi: 10.1093/annonc/mdr135

7. Wang YT, Gou YW, Jin WW, Xiao M, Fang HY. Association between alcohol intake and the risk of pancreatic cancer: a dose-response meta-analysis of cohort studies. BMC Cancer. 2016;16:212. doi:10.1186/s12885-016-2241-1

8. Fedirko V, Tramacere I, Bagnardi V, Rota M, Scotti L, Islami F, Negri E, Straif K, Romieu I, La Vecchia C, Boffetta P, Jenab M. Alcohol drinking and colorectal cancer risk: an overall and dose-response meta-analysis of published studies. Ann Oncol. 2011 Sep;22(9):195872. doi: $10.1093 /$ annonc/mdq653

9. Longnecker MP, Berlin JA, Orza MJ, Chalmers TC. A meta-analysis of alcohol consumption in relation to risk of breast cancer. JAMA. 1988 Aug 5;260(5):652-6.

10. Zhao J, Stockwell T, Roemer A, Chikritzhs T. Is alcohol consumption a risk factor for prostate cancer? A systematic review and metaanalysis. BMC Cancer. 2016;16(1):845. doi:10.1186/s12885-016-2891-z

11. Scoccianti C, Cecchini M, Anderson AS, Berrino F, Boutron- Ruault MC, Espina C, et al. European code against cancer 4th edition: alcohol drinking and cancer. Cancer Epidemiol. 2015;39 Suppl1:S67-74.

12. Bagnardi V, Rota M, Botteri E, Tramacere I, Islami F, Fedirko V, et al. Alcohol consumption and site-specific cancer risk: a comprehensive dose-response meta-analysis. Br J Cancer. 2015 Feb 3;112(3):580-93. doi: 10.1038/bjc.2014.579.

13. Tramacere I, Pelucchi C, Bonifazi M, Bagnardi V, Rota M, Bellocco R, et al. Alcohol drinking and non-Hodgkin lymphoma risk: a systematic review and a meta-analysis. Ann Oncol. 2012 Nov;23(11):2791-8. doi: 10.1093/annonc/mds013 
14. Psaltopoulou T, Sergentanis TN, Ntanasis-Stathopoulos I, Tzanninis IG, Tsilimigras DI, Dimopoulos MA. Alcohol consumption and risk of hematological malignancies: A meta-analysis of prospective studies. Int J Cancer. 2018 Aug 1;143(3):486-495. doi: 10.1002/ijc.31330

15. Islami F, Fedirko V, Tramacere I, Bagnardi V, Jenab M, Scotti L, et al. Alcohol drinking and esophageal squamous cell carcinoma with focus on light-drinkers and never-smokers: a systematic review and meta-analysis. Int J Cancer. 2011 Nov 15;129(10):2473-84. doi: $10.1002 /$ ijc. 25885

16. Tramacere I, Pelucchi C, Bagnardi V, Rota M, Scotti L, Islami F, et al. A meta-analysis on alcohol drinking and esophageal and gastric cardia adenocarcinoma risk. Ann Oncol. 2012 Feb;23(2):287-97. doi: 10.1093/annonc/mdr136

17. He Z, Zhao TT, Xu HM, Wang ZN, Xu YY, Song YX, et al. Association between alcohol consumption and the risk of gastric cancer: a meta-analysis of prospective cohort studies. Oncotarget. 2017 Sep 14;8(48):84459-84472. doi: 10.18632/oncotarget.20880

18. Rota M, Pelucchi C, Bertuccio P, Matsuo K, Zhang ZF, Ito H, et al. Alcohol consumption and gastric cancer risk-A pooled analysis within the StoP project consortium. Int J Cancer. 2017 Nov 15;141(10):1950-1962. doi: 10.1002/ijc.30891

19. Wang YT, Gou YW, Jin WW, Xiao M, Fang HY. Association between alcohol intake and the risk of pancreatic cancer: a dose-response meta-analysis of cohort studies. BMC Cancer. 2016;16:212. Published 2016 Mar 12. doi:10.1186/s12885-016-2241-1

20. Tramacere I, Scotti L, Jenab M, Bagnardi V, Bellocco R, Rota M, et al. Alcohol drinking and pancreatic cancer risk: a meta-analysis of the dose-risk relation. Int J Cancer. 2010 Mar 15;126(6):1474-86. doi: 10.1002/ijc.24936

21. Cho E, Smith-Warner SA, Ritz J, van den Brandt PA, Colditz GA, Folsom AR, et al. Alcohol intake and colorectal cancer: a pooled analysis of 8 cohort studies. Ann Intern Med. 2004 Apr 20;140(8):603-13

22. Fedirko V, Tramacere I, Bagnardi V, Rota M, Scotti L, Islami F, et al. Alcohol drinking and colorectal cancer risk: an overall and doseresponse meta-analysis of published studies. Ann Oncol. 2011 Sep;22(9):1958-72. doi: 10.1093/annonc/mdq653

23. Mizoue T, Inoue M, Wakai K, Nagata C, Shimazu T, Tsuji I, et al. Research Group for Development and Evaluation of Cancer Prevention Strategies in Japan. Alcohol drinking and colorectal cancer in Japanese: a pooled analysis of results from five cohort studies. Am J Epidemiol. 2008 Jun 15;167(12):1397-406. doi: 10.1093/aje/kwn073

24. Wang Y, Duan H, Yang H, Lin J. A pooled analysis of alcohol intake and colorectal cancer. Int J Clin Exp Med. 2015 May 15;8(5):687889.

25. Galeone C, Malerba S, Rota M, Bagnardi V, Negri E, Scotti L, et al.A meta-analysis of alcohol consumption and the risk of brain tumours. Ann Oncol. 2013 Feb;24(2):514-23. doi: 10.1093/annonc/mds432

26. Rota M, Pasquali E, Bellocco R, Bagnardi V, Scotti L, Islami F, et al. Alcohol drinking and cutaneous melanoma risk: a systematic review and dose-risk meta-analysis. Br J Dermatol. 2014 May;170(5):1021-8. doi: 10.1111/bjd.12856

27. Gandini S, Masala G, Palli D, Cavicchi B, Saieva C, Ermini I, et al. Alcohol, alcoholic beverages, and melanoma risk: a systematic literature review and dose-response meta-analysis. Eur J Nutr. 2018 Oct;57(7):2323-2332. doi: 10.1007/s00394-018-1613-5

28. Bagnardi V, Rota M, Botteri E, Scotti L, Jenab M, Bellocco R et al. Alcohol consumption and lung cancer risk in never smokers: a metaanalysis. Ann Oncol. 2011 Dec;22(12):2631-9. doi: 10.1093/annonc/mdr027

29. Choi YJ, Myung SK, Lee JH. Light Alcohol Drinking and Risk of Cancer: A Meta-Analysis of Cohort Studies.Cancer Res Treat. 2018 Apr;50(2):474-487. doi: 10.4143/crt.2017.094.

30. Islami F, Tramacere I, Rota M, Bagnardi V, Fedirko V, Scotti L, et al. Alcohol drinking and laryngeal cancer: overall and dose-risk relationa systematic review and meta-analysis. Oral Oncol. 2010 Nov;46(11):802-10. doi: 10.1016/j.oraloncology.2010.07.015

31. Ellison RC, Zhang Y, McLennan CE, Rothman KJ. Exploring the relation of alcohol consumption to risk of breast cancer. Am J Epidemiol. 2001 Oct 15;154(8):740-7

32. Suzuki R, Orsini N, Mignone L, Saji S, Wolk A. Alcohol intake and risk of breast cancer defined by estrogen and progesterone receptor status-a meta-analysis of epidemiological studies. Int J Cancer. 2008 Apr 15;122(8):1832-41. Erratum in: Int J Cancer. 2008 Aug 15;123(4):981

33. Kelemen LE, Bandera EV, Terry KL, Rossing MA, Brinton LA, Doherty JA, et al. Recent alcohol consumption and risk of incident ovarian carcinoma: a pooled analysis of 5,342 cases and 10,358 controls from the Ovarian Cancer Association Consortium. BMC Cancer. 2013 Jan 22;13:28. doi: 10.1186/1471-2407-13-28

34. Yan-Hong H, Jing L, Hong L, Shan-Shan H, Yan L, Ju L. Association between alcohol consumption and the risk of ovarian cancer: a meta-analysis of prospective observational studies. BMC Public Health. 2015 Mar 7;15:223. doi: 10.1186/s12889-015-1355-8

35. Rota M, Scotti L, Turati F, Tramacere I, Islami F, Bellocco R, et al. Alcohol consumption and prostate cancer risk: a meta-analysis of the dose-risk relation. Eur J Cancer Prev. 2012 Jul;21(4):350-9. doi: 10.1097/CEJ.0b013e32834dbc11

Page 8/18 
36. Zhao J, Stockwell T, Roemer A, Chikritzhs T. Is alcohol consumption a risk factor for prostate cancer? A systematic review and metaanalysis. BMC Cancer. 2016;16(1):845. doi:10.1186/s12885-016-2891-z

37. Mao Q, Lin Y, Zheng X, Qin J, Yang K, Xie L. A meta-analysis of alcohol intake and risk of bladder cancer. Cancer Causes Control. 2010 Nov;21(11):1843-50. doi: 10.1007/s10552-010-9611-9.

38. Pelucchi C, Galeone C, Tramacere I, Bagnardi V, Negri E, Islami F, et al. Alcohol drinking and bladder cancer risk: a meta-analysis. Ann Oncol. 2012 Jun;23(6):1586-93. doi: 10.1093/annonc/mdr460.

39. Cheng G, Xie L. Alcohol intake and risk of renal cell carcinoma: a meta-analysis of published case-control studies. Arch Med Sci. 2011;7(4):648-57.

40. Song DY, Song S, Song Y, Lee JE. Alcohol intake and renal cell cancer risk: a meta-analysis. Br J Cancer. 2012 May 22;106(11):1881-90. doi: 10.1038/bjc.2012.136

41. Bellocco R, Pasquali E, Rota M, Bagnardi V, Tramacere I, Scotti L, et al. Alcohol drinking and risk of renal cell carcinoma: results of a meta-analysis. Ann Oncol. 2012 Sep;23(9):2235-44. doi: 10.1093/annonc/mds022.

42. Bagnardi V, Rota M, Botteri E, Tramacere I, Islami F, Fedirko V, et al. Light alcohol drinking and cancer: a meta-analysis. Ann Oncol. 2013 Feb;24(2):301-8. doi: 10.1093/annonc/mds337

43. Myung SK. Erroneous conclusions about the association between light alcohol drinking and the risk of cancer: comments on Bagnardi et al.'s meta-analysis. An Oncol. 2016;27:2138

44. GBD 2016 Alcohol Collaborators. Alcohol use and burden for 195 countries and territories, 1990-2016: a systematic analysis for the Global Burden of Disease Study 2016. Lancet. 2018 Sep 22;392(10152):1015-1035. doi: 10.1016/S0140-6736(18)31310-2. Epub 2018 Aug 23

45. Ratna A, Mandrekar P. Alcohol and Cancer: Mechanisms and Therapies. Biomolecules. 2017 Aug 14;7(3). pii: E61. doi: 10.3390/biom7030061

46. Baan R, Straif K, Grosse Y, Secretan B, El Ghissassi F, Bouvard V, et al. Carcinogenicity of alcoholic beverages. Lancet Oncol. 2007 Apr;8(4):292-3

47. Boffetta P, Hashibe M. Alcohol and cancer. Lancet Oncol. 2006 Feb;7(2):149-56.

48. Seitz HK, Stickel F. Acetaldehyde as an underestimated risk factor for cancer development: role of genetics in ethanol metabolism. Genes Nutr. 2010 Jun;5(2):121-8. doi: 10.1007/s12263-009-0154-1

49. Goedde HW, Agarwal DP, Fritze G, Meier-Tackmann D, Singh S, Beckmann G, et al. Distribution of ADH2 and ALDH2 genotypes in different populations. Hum Genet. 1992 Jan;88(3):344-6

50. Cao Y, Willett WC, Rimm EB, Stampfer MJ, Giovannucci EL. Light to moderate intake of alcohol, drinking patterns, and risk of cancer: results from two prospective US cohort studies. BMJ. 2015 Aug 18;351:h4238. doi: 10.1136/bmj.h4238

51. Rachdaoui N, Sarkar DK. Effects of alcohol on the endocrine system. Endocrinol Metab Clin North Am. 2013;42(3):593-615.

52. Chen WY, Rosner B, Hankinson SE, Colditz GA, Willett WC. Moderate alcohol consumption during adult life, drinking patterns, and breast cancer risk. JAMA. 2011 Nov 2;306(17):1884-90. doi: 10.1001/jama.2011.1590

53. Liu Y, Nguyen N, Colditz GA. Links between alcohol consumption and breast cancer: a look at the evidence. Womens Health (Lond). 2015;11(1):65-77.

54. Zhao J, Stockwell T, Roemer A, Chikritzhs T. Is alcohol consumption a risk factor for prostate cancer? A systematic review and metaanalysis. BMC Cancer. 2016;16(1):845. doi:10.1186/s12885-016-2891-z

55. Saladi RN, Nektalova T, Fox JL. Induction of skin carcinogenicity by alcohol and ultraviolet light. Clin Exp Dermatol. 2010 Jan;35(1):711. doi: 10.1111/j.1365-2230.2009.03465.x

56. Jiang CH, Sun TL, Xiang DX, Wei SS, Li WQ. Anticancer Activity and Mechanism of Xanthohumol: A Prenylated Flavonoid From Hops (Humulus lupulus). Front Pharmacol. 2018 May 22;9:530. doi: 10.3389/fphar.2018.00530

57. Ko JH, Sethi G, Um JY, Shanmugam MK, Arfuso F, Kumar AP, et al. The Role of Resveratrol in Cancer Therapy. Int J Mol Sci. 2017 Dec 1;18(12). pii: E2589. doi: 10.3390/ijms18122589

58. Schrieks IC, Heil AL, Hendriks HF, Mukamal KJ, Beulens JW. The effect of alcohol consumption on insulin sensitivity and glycemic status: a systematic review and meta-analysis of intervention studies. Diabetes Care. 2015 Apr;38(4):723-32. doi: 10.2337/dc14-1556

59. Facchini F, Chen YD, Reaven GM. Light-to-moderate alcohol intake is associated with enhanced insulin sensitivity. Diabetes Care. 1994 Feb;17(2):115-9

60. Díaz LE, Montero A, González-Gross M, Vallejo Al, Romeo J, Marcos A. Influence of alcohol consumption on immunological status: a review. Eur J Clin Nutr. 2002 Aug;56 Suppl3:S50-3

Page 9/18 
Tables

Page 10/18 


\begin{tabular}{|c|c|c|c|c|c|c|c|c|}
\hline \multirow{2}{*}{$\begin{array}{l}\text {, Year } \\
\text { r, Year }\end{array}$} & \multirow{2}{*}{$\begin{array}{l}\text { Inclusion } \\
\text { Period } \\
\text { InclusionPeriod }\end{array}$} & \multirow{2}{*}{\begin{tabular}{l|}
$\begin{array}{l}\mathrm{N} . \text { of } \\
\text { articles }\end{array}$ \\
$\mathrm{N}$. of \\
articles
\end{tabular}} & \multirow{2}{*}{$\begin{array}{l}\text { Quantity of } \\
\text { alcohol } \\
\text { Quantity of } \\
\text { alcohol }\end{array}$} & \multicolumn{5}{|c|}{ Risk analysis, relative risk (RR) $(95 \% \mathrm{CI})$} \\
\hline & & & & $\begin{array}{l}\text { Consumption results } \\
\text { (dose/day) }\end{array}$ & $\begin{array}{l}\text { Response- } \\
\text { dose } \\
\text { (g/day) }\end{array}$ & $\begin{array}{l}\text { Type of } \\
\text { beverage }\end{array}$ & Sex & $\begin{array}{l}\text { Geographic } \\
\text { region }\end{array}$ \\
\hline \multicolumn{9}{|c|}{ tologic malignances } \\
\hline $\begin{array}{l}\text { icere I } \\
2012\end{array}$ & $1992-2010$ & 29 & $\begin{array}{l}1 \text { drink: } 12.5 \mathrm{~g} \\
\text { of ethanol. } \\
\text { Light drinkers: } \\
\leq 1 / \text { day; } \\
\text { moderate } \\
\text { drinkers: }>1 \text { to } \\
<4 / \text { day; } \\
\text { heavy } \\
\text { drinkers: } \\
\geq 4 \text { /day }\end{array}$ & $\begin{array}{l}\text { Drinkers vs non- } \\
\text { drinkers: } \\
\text { RRs } 0.85 \text { (0.79-0.91). } \\
\leq 1 \text { drink: RRs } 0.88 \\
(0.81-0.96) ; \\
>1-<4 \text { drinks: RRs } 0.87 \\
(0.79-0.95) ; \\
\geq 4 \text { drinks: RRs } 0.84 \\
(0.70-1.00)\end{array}$ & $\begin{array}{l}<10 \text { g/day: } \\
\text { RRs 0.91 } \\
(0.87- \\
0.94) ; \\
10-25 \\
\text { g/day: RRs } \\
0.85 \text { (0.80- } \\
0.90) ; \\
25-50 \\
\text { g/day: RRs } \\
0.80 \text { (0.74- } \\
0.87) ; \\
50-75 \\
\text { g/day: RRs } \\
0.80 \text { (0.70- } \\
0.91) ; \\
75-100 \\
\text { g/day: } \\
\text { RRs 0.81 } \\
\text { (0.66-1.00) }\end{array}$ & & $\begin{array}{l}\text { Male: RRs } 0.83 \\
(0.75-0.92) ; \\
\text { Female: RRs } \\
0.86(0.76- \\
0.98)\end{array}$ & $\begin{array}{l}\text { Asia: RRs } 0.69 \\
(0.57-0.84) \\
\text { Non asia: RRs } \\
0.88(0.82- \\
0.93)\end{array}$ \\
\hline $\begin{array}{l}\text { poulou } \\
\text { l. } 2018\end{array}$ & $\begin{array}{l}\text { Until August } \\
2016\end{array}$ & 53 & $\begin{array}{l}1 \text { drink: } 12.5 \mathrm{~g} \\
\text { of ethanol. } \\
\text { Light drinkers: } \\
\leq 12.5 \mathrm{~g} / \text { day; } \\
\text { moderate } \\
\text { drinkers: } \\
>12.5 \text { to } 50 \\
\text { g/day; } \\
\text { heavy } \\
\text { drinkers: } \\
\geq 50 \mathrm{~g} / \text { day }\end{array}$ & $\begin{array}{l}\text { Drinkers vs non- } \\
\text { drinkers: } \\
\text { RRs } 0.89 \text { (0.83- } \\
0.95) \text {. } \\
\leq 1 \text { drink: RRs } 0.93 \text { (0.87- } \\
1.00) \\
>1-<4 \text { drinks: RRs } 0.85 \\
(0.80-0.90) \\
\geq 4 \text { drinks: } R R=0.73 \\
(0.60-0.89)\end{array}$ & & $\begin{array}{l}\text { Beer: } \\
\text { RRs 0.88 } \\
(0.81-0.95) \\
\text { Wine: RRs } \\
0.96(0.90- \\
1.12) \\
\text { Liquor: } \\
\text { RRs } 0.90 \\
(0.79-1.02)\end{array}$ & $\begin{array}{l}\text { Male: } \\
\text { RRs 0.88, } \\
(0.78-0.98) \\
\text { Female: RRs } \\
0.94, \\
(0.83-1.07)\end{array}$ & \\
\hline \multicolumn{9}{|c|}{ agealcancer } \\
\hline F et & $1961-2010$ & 53 & $\begin{array}{l}1 \text { drink: } 12.5 \mathrm{~g} \\
\text { of ethanol. } \\
\text { Light drinkers: } \\
\leq 1 \text { drink/day; } \\
\text { Moderate } \\
\text { drinkers: }>1 \text { to } \\
<4 \text { drinks/day } \\
\text { Heavy } \\
\text { drinkers: } \geq 4 \\
\text { drinks/day }\end{array}$ & $\begin{array}{l}\leq 1 \text { drink:RRs } 1.31 \text { (1.10- } \\
1.57) \\
>1-<4 \text { drinks: RRs } 2.27 \\
(1.89-2.72) \\
\geq 4 \text { drinks: RRs } 4.89 \\
(3.84-6.23)\end{array}$ & & & & $\begin{array}{l}\leq 1 \text { drink/day } \\
\text { Asia: RRs } 1.63 \\
(1.20-2.22) \\
\text { Non Asia: RRs } \\
1.17 \text { (0.99- } \\
1.39) \\
>1 \text { to < } 4 \\
\text { drinks/day } \\
\text { Asia: RRs } 2.17 \\
\text { (1.58-2.96) } \\
\text { Non Asia: RRs } \\
2.34 \text { (1.9- } \\
2.88) . \geq 4 \\
\text { drinks/day } \\
\text { Asia: RRs } 4.02 \\
\text { (2.76-5.83) } \\
\text { Non Asia: RRs } \\
5.73 \text { (4.41- } \\
7.44) \\
\end{array}$ \\
\hline icere I & $1989-2010$ & 24 & $\begin{array}{l}1 \text { drink: } 12.5 \mathrm{~g} \\
\text { of ethanol. } \\
\text { Light drinkers: } \\
\leq 1 \text { drink/day; } \\
\text { Moderate } \\
\text { drinkers: }>1 \text { to } \\
<4 \text { drinks/day } \\
\text { Heavy } \\
\text { drinkers: } \geq 4 \\
\text { drinks/day }\end{array}$ & $\begin{array}{l}\text { Drinkers vs } \\
\text { nondrinkersOesophageal } \\
\text { carcinoma: RRs } 0.87 \\
(0.74-1.01) \text { Gastric } \\
\text { cardia } \\
\text { adenocarcinoma:RRs } \\
0.89 \text { (0.76-1.03) } \\
\leq 1 \text { drink/day: RRs } 0.86 \\
(0.75-0.99)\end{array}$ & $\begin{array}{l}\text { No } \\
\text { increase in } \\
\text { risk up to } \\
70 \text { g/day }\end{array}$ & & $\begin{array}{l}\text { Male: } \\
\text { RRs } 1.02(0.69- \\
1.49) \\
\text { Female: } \\
\text { RRs 0.86 (0.68- } \\
1.07)\end{array}$ & \\
\hline
\end{tabular}




\begin{tabular}{|c|c|c|c|c|c|c|c|c|}
\hline & & & & $\begin{array}{l}>1 \text { to }<4 \text { drinks/day: } \\
\text { RRs } \\
0.90(0.73-1.10) \\
\geq 4 \text { drinks/day: RRs } 1.16 \\
(0.92-1.46)\end{array}$ & & & & \\
\hline \multicolumn{9}{|c|}{ ccancer } \\
\hline t al. & 1984-2015 & 22 & & $\begin{array}{l}\text { Drinkers vs. non } \\
\text { drinkers: RRs } 1.03 \\
(0.99-1.08) . \text { Light } \\
\text { drinkers: RRs } 0.95 \\
(0.88-1.02) \text {. } \\
\text { Moderate drinkers: RRs } \\
1.05 \text { (0.98-1.13). Heavy } \\
\text { drinkers: RRs: } 1.13 \\
(1.06-1.21)\end{array}$ & $\begin{array}{l}\text { No } \\
\text { increased } \\
\text { risk up to } \\
60 \mathrm{~g} / \text { day }\end{array}$ & & $\begin{array}{l}\text { Light drinkers } \\
\text { Male: RRs } 0.96 \\
(0.90-1.03) \\
\text { Female: RRs } \\
0.74 \text { (0.57-0.98) } \\
\text { Heavy drinkers } \\
\text { Male: RRs } 1.13 \\
\text { (1.06-1.22) } \\
\text { Female: RRs } \\
1.33(0.79-2.24) \\
\end{array}$ & $\begin{array}{l}\text { Heavy } \\
\text { drinkers } \\
\text { Non Asia: RRs } \\
1.20 \text { (1.03- } \\
\text { 1.41) } \\
\text { Asia: RRs 1.12 } \\
(\mathbf{1 . 0 4 - 1 . 2 0 )}\end{array}$ \\
\hline M et al. & $1989-2015$ & 23 & $\begin{array}{l}1 \text { drink=12 g } \\
\text { of ethanol } \\
\text { categorized } \\
\text { across studies } \\
\text { as: } \\
\leq 1 \text { drink/day; } \\
>1 \text { to } 4 \\
\text { drinks/day; } \\
>4 \text { to } 6 \\
\text { drinks/day; } \\
>6 \text { to } 8 \\
\text { drinks/day; } \\
>8 \text { drinks/day }\end{array}$ & $\begin{array}{l}\text { Drinkers vs no drinkers: } \\
\text { RRs } 1.10 \text { (0.99-1.21) } \\
\leq 1: \text { drink RRs } 1.00 \\
(0.86-1.16) \\
>1-4 \text { drinks: RRs } 1.11 \\
(1.01-1.23) \\
>4-6 \text { drinks: RRs } 1.26 \\
\text { (1.08-1.48) } \\
>6 \text { drinks: RRs } 1.48 \\
\text { (1.29-1.70) } \\
>6-8 \text { drinks: RRs } 1.46 \\
(1.18-1.80) ; \\
>8 \text { drinks: RRs } 1.50 \\
(1.26-1.78)\end{array}$ & $\begin{array}{l}6 \text { g/day: } \\
\text { RRs 1.02 } \\
\text { (1.01-1.03) } \\
30 \text { g/day: } \\
\text { RRs } 1.11 \\
(1.05-1.17) \\
60 \text { g/day: } \\
\text { RRs } 1.24 \\
(1.11-1.38) \\
84 \text { g/day: } \\
\text { RRs 1.34 } \\
(1.15-1.57) \\
100 \text { g/day: } \\
\text { RRs 1.42 } \\
\text { (1.15-1.57) }\end{array}$ & $\begin{array}{l}\text { Wine } \\
>0 \text { to } 1 \\
\text { drink/day: } \\
\text { RRs } 1.03 \\
(0.80- \\
1.31) \\
>1 \text { to } 3 \\
\text { drinks/day: } \\
\text { RRs } 1.22 \\
(1.02- \\
1.45) \\
>3 \\
\text { drinks/day: } \\
\text { RRs } 1.44 \\
(0.98- \\
2.11) \\
\text { Beer } \\
>0 \text { to } 1 \\
\text { drink/day: } \\
\text { RRs } 1.33 \\
(0.97- \\
1.83) \\
>1 \\
\text { drink/day: } \\
\text { RRs } 1.27 \\
(0.89- \\
1.82) \\
\text { Spirit } \\
>0 \text { to } 1 \\
\text { drink/day: } \\
\text { RRs } 0.94 \\
(0.70- \\
1.27) \\
>1 \\
\text { drink/day: } \\
\text { RRs } 1.66 \\
(1.23- \\
2.22) \\
\end{array}$ & & \\
\hline \multicolumn{9}{|c|}{ eatic cancer } \\
\hline YT et & & 19 & $\begin{array}{l}1 \text { drink: } 12 \mathrm{~g} \\
\text { of ethanol } \\
\text { Light drinkers: } \\
0-12 \mathrm{~g} / \text { day } \\
\text { Moderate } \\
\text { drinkers; } 12 \text { - } \\
24 \mathrm{~g} / \text { day } \\
\text { Heavy } \\
\text { drinkers: } \\
\geq 24 \mathrm{~g} / \text { day } \\
\end{array}$ & $\begin{array}{l}1 \text { drink: RRs } 0.97 \text { (0.89- } \\
1.05) \text {; } \\
\text { 1-2 drinks: RRs } 0.98 \\
\text { (0.93-1.03) } \\
\text { Total alcohol intake: RRs } \\
1.02 \text { (0.95-1.08) } \\
\geq 2 \text { : RRs } 1.15 \text { (1.06-1.25) }\end{array}$ & $\begin{array}{l}\text { No linear } \\
\text { relationship } \\
\text { up to } 55 \\
\text { g/day }\end{array}$ & $\begin{array}{l}\text { Liquor } \\
\geq 24 \text { g/day: } \\
\text { RRs } 1.43 \\
(1.17-1.74)\end{array}$ & $\begin{array}{l}\geq 24 \mathrm{~g} / \text { day } \\
\text { Male: RRs } 1.18 \\
(1.00-1.39) \\
\text { Female: RRs } \\
1.07(0.96-1.19)\end{array}$ & \\
\hline icere I & $1983-2009$ & 32 & $\begin{array}{l}1 \text { drink: } 12.5 \mathrm{~g} \\
\text { of ethanol. }\end{array}$ & $\begin{array}{l}<3 \text { drinks: RRs } 0.92 \\
(0.86-0.97)\end{array}$ & $\begin{array}{l}25 \text { g/day: } \\
\text { RRs } 1.03\end{array}$ & & $\begin{array}{l}\geq 5 \text { drinks/day } \\
\text { Male: RRs } 1.17\end{array}$ & \\
\hline
\end{tabular}




\begin{tabular}{|c|c|c|c|c|c|c|}
\hline & & & $\begin{array}{l}\text { Moderate } \\
\text { drinkers: <3 } \\
\text { drinks/day } \\
\text { Heavy drinkes: } \\
\geq 3 \text { drinks/day }\end{array}$ & $\begin{array}{l}\geq 3 \text { drinks: RRs } 1.22 \\
(1.12-1.34)\end{array}$ & $\begin{array}{l}\text { (0.99-1.07) } \\
50 \text { g/day: } \\
\text { RRs } 1.10 \\
(1.02-1.20) \\
75 \text { g/day: } \\
\text { RRs } 1.19 \\
(1.06-1.35) \\
100 \text { g/day: } \\
\text { RRs } 1.30 \\
(1.08-1.55) \\
125 \text { g/day: } \\
\text { RRs } 1.40 \\
(1.06-1.85)\end{array}$ & $\begin{array}{l}(0.99-1.38) \\
\text { Female: RRs } \\
0.79(0.43-1.44) \\
\geq 7 \\
\text { drinks/dayMale: } \\
1.27 \text { (1.03-1.56) } \\
\text { Female: RRs } \\
0.78(0.40-1.51)\end{array}$ \\
\hline \multicolumn{7}{|c|}{$30-<45 \mathrm{~g} /$ day: $R R=1.21$} \\
\hline et al. & 1980-1998 & 8 & $\begin{array}{l}1 \text { drink: } 12.8 \mathrm{~g} \\
\text { of ethanol. }\end{array}$ & $\begin{array}{l}30-<45 \mathrm{~g} / \text { day: } R R=1.21 \\
(1.04-1.42) \\
\geq 45 \text { g/day: } R R=1.51 \\
(1.25-1.83)\end{array}$ & \begin{tabular}{|l|}
$>0-<5$ \\
g/day: RRs \\
$0.94(0.86-$ \\
$1.03) ;$ \\
$5-<15$ \\
g/day: RRs \\
0.97 (0.88- \\
$1.06)$ \\
$15-<30$ \\
g/day: RRs \\
1.01 (0.86- \\
$1.18)$ \\
$30-<45$ \\
g/day: RRs \\
1.16 (0.99- \\
$1.36)$ \\
$>45$ g/day: \\
RRs 1.41 \\
(1.16-1.72) \\
\end{tabular} & \\
\hline so V et & $1979-2007$ & $\begin{array}{l}61 \\
\text { studies }\end{array}$ & $\begin{array}{l}1 \text { drink }=12.5 \\
\text { g of ethanol. } \\
\text { Light drinkers: } \\
\leq 1 \text { drink/day } \\
\text { ( } \leq 12.5 \mathrm{~g} / \text { day } \\
\text { of ethanol) } \\
\text { Moderate } \\
\text { drinkers: } 2-3 \\
\text { drinks/day } \\
\text { (12.6-49.9 } \\
\text { g/day of } \\
\text { ethanol) } \\
\text { Heavy } \\
\text { drinkers: } \geq 4 \\
\text { drinks/day } \\
\text { ( } \geq 50 \mathrm{~g} / \text { day of } \\
\text { ethanol). }\end{array}$ & $\begin{array}{l}\text { Drinkers vs non } \\
\text { drinkers: RRs } 1.12 \\
(1.06-1.19) \leq 1 \text { drink: } \\
\text { RRs } 1.00 \text { (0.95-1.05) } \\
2-3 \text { drinks: RRs } 1.21 \\
\text { (1.13-1.28) } \\
\geq 4 \text { drinks: RRs } 1.52 \\
(1.27-1.81)\end{array}$ & \begin{tabular}{|l|}
$10:$ RRs \\
$1.07(1.04-$ \\
$1.10)$ \\
$25:$ RRs \\
$1.18(1.12-$ \\
$1.25)$ \\
$50:$ RRs \\
$1.38(1.28-$ \\
$1.50)$ \\
$100:$ RRs \\
$1.82(1.41-$ \\
$2.35)$
\end{tabular} & $\begin{array}{l}\text { Any drinker } \\
\text { Male: RRs } 1.25 \\
(1.13-1.39) \\
\text { Female: RRs } 1 \\
(0.94-1.07) \\
\text { p=0.001. } 2-3 \\
\text { drinks/day } \\
\text { Male: RRs } 1.24 \\
(1.13-13) \\
\text { Female: RRs } \\
1.08(1.03-1.1) \\
\mathrm{p}=0.02\end{array}$ \\
\hline e T et & 1988 to 2004 & 5 & \begin{tabular}{|l} 
nondrinkers \\
(never and ex- \\
drinkers), \\
occasional \\
drinkers \\
(<once/week), \\
and regular \\
drinkers \\
( $\geq$ once/week: \\
for men, 0.1- \\
$22.9 \mathrm{~g} /$ day, \\
$23-45.9 \mathrm{~g} /$ day, \\
$46-68.9 \mathrm{~g} /$ day, \\
$69-91.9 \mathrm{~g} /$ day, \\
or $\geq 92 \mathrm{~g} /$ day; \\
for women,
\end{tabular} & $\begin{array}{l}\text { increased risk of } \\
\text { colorectal cancer in a } \\
\text { dose-response manner in } \\
\text { men RRs: for } 23-45.9 \\
\text { g/day, } 46-68.9 \text { g/day, } \\
69-91.9 \mathrm{~g} / \text { day, and } \geq 92 \\
\text { g/day (compared with } \\
\text { nondrinking) were } 1.42 \\
(1.21,1.66), 1.95(1.53 \text {, } \\
2.49), 2.15(1.74,2.64) \text {, } \\
\text { and } 2.96(2.27,3.86), \\
\text { respectively }\end{array}$ & & $\begin{array}{l}\text { Colorectal } \\
\text { cancer: } 0.1-4.9 \\
\text { g/day, 5-14.9 } \\
\text { g/day, } 15-29.9 \\
\text { g/day, 30-44.9 } \\
\text { g/day, and } \geq 45 \\
\text { g/day were } 1.11 \\
(0.74,1.67), \\
1.10(0.86, \\
1.42), 1.35 \\
(1.10,1.66), \\
1.61(1.32, \\
1.95), \text { and } 2.09 \\
(1.65,2.64) . \\
\text { Women: } 0.1- \\
22.9 \text { g/day; } \geq 23 \\
\text { g/day } 0.93(0.7-\end{array}$ \\
\hline
\end{tabular}




\begin{tabular}{|c|c|c|c|c|c|c|c|c|}
\hline & & & $\begin{array}{l}0.1-22.9 \mathrm{~g} / \text { day } \\
\text { or } \geq 23 \mathrm{~g} / \text { day }\end{array}$ & & & & $\begin{array}{l}1.23) ; 1.57 \\
(1.11-2.21) \\
\text { respectively }\end{array}$ & \\
\hline $\bar{Y}$ et & 1991-2013 & 24 & $\begin{array}{l}1 \text { drink }=12.5 \\
\text { g of ethanol } \\
\text { Light drinkers: } \\
\leq 1 \text { drink/day } \\
\text { ( } \leq 12.5 \mathrm{~g} / \text { day } \\
\text { of ethanol) } \\
\text { Moderate } \\
\text { drinkers: } 2-3 \\
\text { drinks/day } \\
\text { (12.6-49.9 } \\
\text { g/day of } \\
\text { ethanol) } \\
\text { Heavy } \\
\text { drinkers: } \geq 4 \\
\text { drinks/day } \\
\text { ( } \geq 50 \mathrm{~g} / \text { day of } \\
\text { ethanol). }\end{array}$ & $\begin{array}{l}\text { Drinkers vs. non } \\
\text { drinkers: RRs } 1.13 \text { (95\% } \\
\text { CI, 1.09-1.17) } \\
\leq 1 \text { drink: RRs } 1.07 \text { (95\% } \\
\text { CI, 1.02-1.13) } \\
\text { >1- } 3 \text { drinks: RRs } 1.23 \\
\text { (1.15-1.32) }\end{array}$ & & & $\begin{array}{l}\text { Male: RRs 1.11, } \\
(1.00-1.23) \\
\text { Female: RRs } \\
1.03,(0.95- \\
1.10)\end{array}$ & $\begin{array}{l}\text { Asia: RRs } 1.19 \\
(1.11-1.27) \\
\text { Europe: RRs } \\
1.22(1.10- \\
1.34) \\
\text { US: RRs 1.10, } \\
(1.05-1.15)\end{array}$ \\
\hline \multicolumn{9}{|l|}{ cancer } \\
\hline $\begin{array}{l}\text { ne C. } \\
2013\end{array}$ & & 20 & $\begin{array}{l}1 \text { drink: } 12.5 \mathrm{~g} \\
\text { of ethanol. } \\
\text { Moderate } \\
\text { drinkers: }<25 \\
\mathrm{~g} \text { of } \\
\text { ethanol/day } \\
\text { Heavy } \\
\text { drinkers: } \geq 25 \\
\text { g of } \\
\text { ethanol/day }\end{array}$ & $\begin{array}{l}\text { Drinkers versus non- } \\
\text { drinkers: RRs } 0.97 \\
(0.82-1.15) \\
\text { Moderate drinkers: RRs } \\
1.01 \text { (0.81-1.25) Heavy } \\
\text { drinkers: RR } 1.35 \text { (0.85- } \\
2.15)\end{array}$ & & $\begin{array}{l}\text { Wine: RRs } \\
1.01 \text { (0.70- } \\
1.48) \\
\text { Beer: RRs } \\
0.96(0.82- \\
1.12) \\
\text { Spirits: } \\
\text { RRs } 1.20 \\
(1.01- \\
1.42) \\
\end{array}$ & 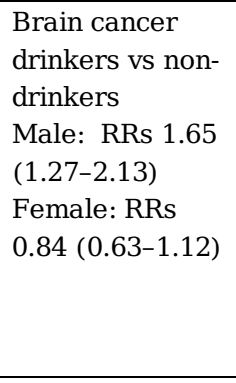 & $\begin{array}{l}\text { America: RRs } \\
0.74 \text { (0.63- } \\
0.89) \\
\text { Europe: RRs } \\
1.05(0.94- \\
1.16) \\
\text { Asia/Australia: } \\
\text { RRs } 1.16 \\
(0.87-1.63)\end{array}$ \\
\hline \multicolumn{9}{|c|}{ eous melanoma } \\
\hline $\begin{array}{l}\text { M. et } \\
14\end{array}$ & $1986-2009$ & 16 & $\begin{array}{l}1 \text { drink: } 12.5 \mathrm{~g} \\
\text { of ethanol. } \\
\text { Light drinkers: } \\
\leq 1 \text { drink, or } \\
\leq 12,5 \mathrm{~g} \text { of } \\
\text { ethanol/day } \\
\text { Moderate to } \\
\text { heavy } \\
\text { drinkers: }>1 \\
\text { drink, or }>12,5 \\
\mathrm{~g} \text { of } \\
\text { ethanol/day }\end{array}$ & $\begin{array}{l}\text { Drinkers vs } \\
\text { no/occasional drinkers: } \\
\text { RRs } 1.20 \text { (1.06- } \\
1.37) \\
\leq 1 \text { drink: RRs } 1.10 \\
\text { (0.96-1.26) } \\
>1 \text { drinks: RRs } 1.18 \\
(1.01-1.40)\end{array}$ & $\begin{array}{l}12 \text { g/day: } \\
\text { RRs } \\
1.11 \text { (1.01- } \\
1.23) \\
25 \text { g/day: } \\
\text { RRs } 1.25 \\
\text { (1.01-1.53) } \\
50 \text { g/day: } \\
\text { RRs } 1.55 \\
\text { (1.02-2.35) }\end{array}$ & & $\begin{array}{l}\text { Male: RRs } 1.47 \\
(0.94-2.29) ; \\
\text { Women: RRs } \\
1.26,(1.19- \\
1.35)\end{array}$ & $\begin{array}{l}\text { Australia: RRs } \\
1.20 \text { (0.87 } \\
-1.66) \text { Europe: } \\
\text { RRs } 1.04 \text { (0.79 } \\
-1.37) \\
\text { America: RRs } \\
1.41 \text { (1.21- } \\
1.66)\end{array}$ \\
\hline $\begin{array}{l}\text { ni S et } \\
18\end{array}$ & $1986-2016$ & 20 & $\begin{array}{l}1 \text { drink } \\
=12 \mathrm{~g} \text { of } \\
\text { ethanol }\end{array}$ & $\begin{array}{l}\text { Highest vs. lowest } \\
\text { category of actual } \\
\text { alcohol intake: RRs } 1.29 \\
(1.14-1.45)\end{array}$ & $\begin{array}{l}\text { For an } \\
\text { increase of } \\
10 \mathrm{~g} / \text { day: } \\
\text { RRs } 1.07 \\
(1.03-1.11)\end{array}$ & $\begin{array}{l}\text { Wine: RRs } \\
1.22(0.95- \\
1.57) \\
\text { Beer: RRs } \\
1.03(0.81- \\
1.29) \\
\text { Liquor: } \\
\text { RRs } 1.08 \\
(0.91- \\
1.28)\end{array}$ & & \\
\hline \multicolumn{9}{|l|}{ cancer } \\
\hline $\begin{array}{l}\text { Irdi V } \\
2011\end{array}$ & $1988-2010$ & 10 & $\begin{array}{l}1 \text { drink: } 12.5 \mathrm{~g} \\
\text { of ethanol }\end{array}$ & $\begin{array}{l}\text { Never smokers } \\
\text { Drinkers vs non } \\
\text { drinkers: RRs } 1.21 \\
(0.95-1.55)\end{array}$ & $\begin{array}{l}\text { For an } \\
\text { increase of } \\
10 \mathrm{~g} / \text { day up } \\
\text { to } 75 \mathrm{~g} / \text { day: } \\
\text { RRs } 1.01 \\
(0.92-1.10)\end{array}$ & & & \\
\hline J et al. & & & & & & & & \\
\hline \multicolumn{9}{|c|}{$\mathrm{x}$ cancer } \\
\hline & & & & & & & & \\
\hline
\end{tabular}




\begin{tabular}{|c|c|c|c|c|c|c|c|}
\hline $\begin{array}{l}\text { F et } \\
10\end{array}$ & $1956-2009$ & 40 & $\begin{array}{l}1 \text { drink = } 12.5 \\
\text { g. } \\
\text { Light } \\
\text { drinkers: } \\
\leq 12.5 \mathrm{~g} \\
\text { ethanol = } \leq \\
1 \text { drink } / \text { day } \\
\text { Moderate } \\
\text { drinkers: } \\
>12.5 \text { to }<50 \mathrm{~g} \\
\text { ethanol = >1 } \\
\text { to }<4 \\
\text { drinks } / \text { day } \\
\text { Heavy } \\
\text { drinkers: } \geq 50 \\
\text { g ethanol = } \\
\geq 4 \text { drinks } / \text { day }\end{array}$ & $\begin{array}{l}\text { Drinkers vs } \\
\text { no/occasional drinkers: } \\
\text { RRs } 1.84(1.50-2.26) \leq 1 \\
\text { drink: RRs } \\
0.88(0.70-1.12)>1-4 \text { : } \\
\text { RRs } 1.50(1.23-1.83) ; \\
\geq 4 \text { : RRs } 2.46 \\
(1.88-3.22)\end{array}$ & $\begin{array}{l}12.5 \text { g/day: } \\
\text { RRs } \\
1.20 \text { (1.15- } \\
1.25) \\
25 \text { g/day: } \\
\text { RRs } 1.45 \\
(1.33-1.57) \\
37,5 \text { g/day: } \\
\text { RRs } 1.72 \\
(1.52- \\
1.90) \\
50 \text { g/day: } \\
\text { RRs } 2.04 \\
(1.76-2.36) \\
100 \text { g/day: } \\
\text { RRs 3.77 } \\
(2.93-4.86)\end{array}$ & & \\
\hline \multicolumn{8}{|c|}{ avity and pharynx cancer } \\
\hline $\begin{array}{l}\text { a RC et } \\
31\end{array}$ & 1966-1999 & 42 & $\begin{array}{l}\text { Based on the } \\
\text { categories } \\
\text { reported in the } \\
\text { original paper }\end{array}$ & $\begin{array}{l}6 \text { g/day: RRs } 4.9 \% \text { (1.03- } \\
1.07) \text {; } \\
12 \text { g/day: RRs } 10 \% \\
\text { increased risk (1.06- } \\
1.14 \text { ); } \\
24 \text { g/day: RRs } 21 \% \\
\text { increased risk (1.13- } \\
1.30 \text { ) }\end{array}$ & & $\begin{array}{l}\text { Beer: RRs } \\
0.96(0.91- \\
1.02) \\
\text { Spirits: } \\
\text { RRs 1.01 } \\
(0.93-1.09)\end{array}$ & $\begin{array}{l}\text { US: RRs } 1 \\
\text { Outside US: } \\
\text { RRs } 1.05 \\
(0.99-1.12)\end{array}$ \\
\hline $\begin{array}{l}\text { i R. et } \\
\text { )7 }\end{array}$ & $1970-2007$ & 20 & 1 drink $=10 \mathrm{~g}$ & $\begin{array}{l}\text { Highest vs lowest } \\
\text { category of alcohol } \\
\text { intake: ER+ tumors: RRs } \\
1.27 \text { (1.17-1.38); } \\
\text { ER- tumors: RRs } 1.14 \\
(1.03-1.26) ; \\
\text { ER+ PR+ tumors: RRs } \\
1.22(1.11-1.34) ; \\
\text { ER+PR- tumors: RRs } \\
1.28 \text { (1.07-1.53) }\end{array}$ & $\begin{array}{l}\text { For an } \\
\text { increase in } \\
\text { alcohol } \\
\text { intake of } 10 \\
\text { g/day up to } \\
40 \text { g/day } \\
\text { ER+ } \\
\text { tumors: } \\
\text { RRs } 12 \% \\
\text { (8\%-15\%); } \\
\text { ER- tumors: } \\
\text { RRs } 7 \% \\
(0 \%-14 \%) ; \\
\text { ER+PR+ } \\
\text { tumors: } \\
\text { RRs } 11 \% \\
\text { (7\%-14\%); } \\
\text { ER+PR- } \\
\text { tumors: } \\
\text { RRs } 15 \% \\
\text { (2\%-30\%) }\end{array}$ & & \\
\hline \multicolumn{8}{|l|}{ t cancer } \\
\hline $\begin{array}{l}\text { Ien LE } \\
2013\end{array}$ & $1989-2009$ & 12 & $\begin{array}{l}1 \text { drink of } \\
\text { alcohol from } \\
\text { any source = } \\
10 \mathrm{~g} ; \\
1 \mathrm{drink} \text { of beer } \\
=12.2 \mathrm{~g} \text {; } \\
1 \text { drink of wine } \\
=10.5 \mathrm{~g} \\
1 \text { drink of } \\
\text { liquor }=9.5 \mathrm{~g} \text {. } \\
\text { Alcohol intake } \\
\text { categories } \\
\text { were derived } \\
\text { in increments } \\
\text { of one } \\
\text { standard drink }\end{array}$ & $\begin{array}{l}\text { Drinkers vs non drinkers } \\
\text { of alcohol from any } \\
\text { source } \\
1 \text { drink: RRs } 0.94 \text { (0.85- } \\
1.03) \text {; } \\
\text { 1-2 drinks: RRs } 0.97 \\
\text { (0.85-1.11); } \\
\text { 2-3 drinks: RRs } 0.91 \\
(0.74-1.11) ; \\
\geq 3 \text { drinks: RRs } 0.92 \\
(0.76-1.10)\end{array}$ & & $\begin{array}{l}\text { Beer } \\
\text { Up to } 1 \\
\text { drink/day: } \\
\text { RRs 0.92 } \\
\text { (0.83- } \\
1.02) ; \\
\geq 1 \\
\text { drink/day: } \\
\text { RRs1.09 } \\
\text { (0.86- } \\
1.37) \text {. } \\
\text { Wine } \\
\text { Up to } 1 \\
\text { drink/day: } \\
\text { RRs 0.94 } \\
\text { (0.85- } \\
1.04) ;\end{array}$ & \\
\hline
\end{tabular}




\begin{tabular}{|c|c|c|c|c|c|c|c|}
\hline & & & & & & $\begin{array}{l}1-2 \\
\text { drinks/day: } \\
\text { RRs } 1.00 \\
(0.83- \\
1.20) \text {; } \\
\geq 2 \\
\text { drinks/day: } \\
\text { RRs } 0.83 \\
(0.68- \\
1.01) \text {. } \\
\text { Liquor } \\
\text { Up to } 1 \\
\text { drink/day: } \\
\text { RRs } 0.97 \\
(0.88- \\
1.08) \text {; } \\
\geq 1 \\
\text { drink/day: } \\
\text { RRs } 1.03 \\
\text { (0.85-1.26) }\end{array}$ & \\
\hline $\begin{array}{l}\text { ong Y. } \\
2015\end{array}$ & $1997-2012$ & 13 & $\begin{array}{l}\text { Low alcohol } \\
\text { intake: } \leq 15 \mathrm{~g} \\
\text { ethanol/day } \\
\text { Moderate } \\
\text { alcohol intake: } \\
15-30 \mathrm{~g} \\
\text { ethanol/day } \\
\text { Heavy alcohol } \\
\text { intake: } \geq 30 \mathrm{~g} \\
\text { ethanol/day }\end{array}$ & $\begin{array}{l}\text { Drinkers vs } \\
\text { no/occasional drinkers: } \\
\text { RRs } 1.03 \text { (0.96-1.10); } \\
\text { Low alcohol intake: RRs } \\
1.02(0.94-1.11) \text {; } \\
\text { Moderate alcohol intake: } \\
\text { RRs } 1.18 \text { (0.98-1.42); } \\
\text { Heavy alcohol intake: } \\
\text { RRs } 1.13 \\
(0.90-1.41)\end{array}$ & & & $\begin{array}{l}\text { Low alcohol } \\
\text { intake } \\
\text { US: RRs } 1.01 \\
(0.92-1.12) ; \\
\text { Other: RRs: } \\
0.96 \text { (0.92- } \\
1.00)\end{array}$ \\
\hline \multicolumn{8}{|c|}{ an cancer } \\
\hline M et al. & 1971-2010 & 72 & $\begin{array}{l}1 \text { drink = } 12.5 \\
\text { g of ethanol } \\
\text { Light } \\
\text { drinkers: } \\
\leq 12.5 \mathrm{~g} \\
\text { ethanol = } \leq \\
1 \text { drink/day } \\
\text { Moderate } \\
\text { drinkers: } \\
>12.5 \text { to }<50 \mathrm{~g} \\
\text { ethanol = >1 } \\
\text { to }<4 \\
\text { drinks/day } \\
\text { Heavy } \\
\text { drinkers: } \geq 50 \\
\text { g ethanol = } \\
\geq 4 \text { drinks } / \text { day }\end{array}$ & $\begin{array}{l}\text { Drinkers vs } \\
\text { no/occasional drinkers: } \\
\text { RRs } 1.06 \text { (1.01-1.10); } \\
\text { Light drinkers: RRs } 1.05 \\
(1.02-1.08) ; \\
\text { Moderate drinkers: RRs } \\
1.06 \text { (1.01-1.11); } \\
\text { Heavy drinkers: RRs } \\
1.08 \text { (0.97-1.20) }\end{array}$ & $\begin{array}{l}10 \text { g/day: } \\
\text { RRs } 1.02 \\
(1.00- \\
1.04) ; \\
25 \mathrm{~g} / \text { day: } \\
\text { RRs } 1.05 \\
(1.01- \\
1.09) ; \\
50 \mathrm{~g} / \text { day: } \\
\text { RRs } 1.09 \\
(1.02- \\
1.16) ; \\
100 \mathrm{~g} / \text { day: } \\
\text { RRs } 1.12 \\
(0.97-1.30)\end{array}$ & & \\
\hline I et al, & $1990-2014$ & 27 & $\begin{array}{l}1 \text { drink = } 8 \\
\text { g/drink for the } \\
\text { UK; } 10 \mathrm{~g} / \text { drink } \\
\text { for Australia, } \\
\text { Austria, } \\
\text { France, } \\
\text { Greece, } \\
\text { Hungary, } \\
\text { Ireland, } \\
\text { Netherlands, } \\
\text { New Zealand, } \\
\text { Poland, Spain, } \\
\text { Sweden; } 11 \\
\text { g/drink for } \\
\text { Finland; } 12 \\
\text { g/drink for } \\
\text { Denmark, }\end{array}$ & 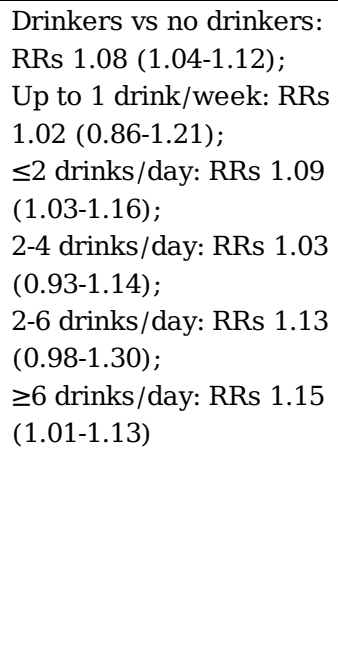 & & & \\
\hline
\end{tabular}




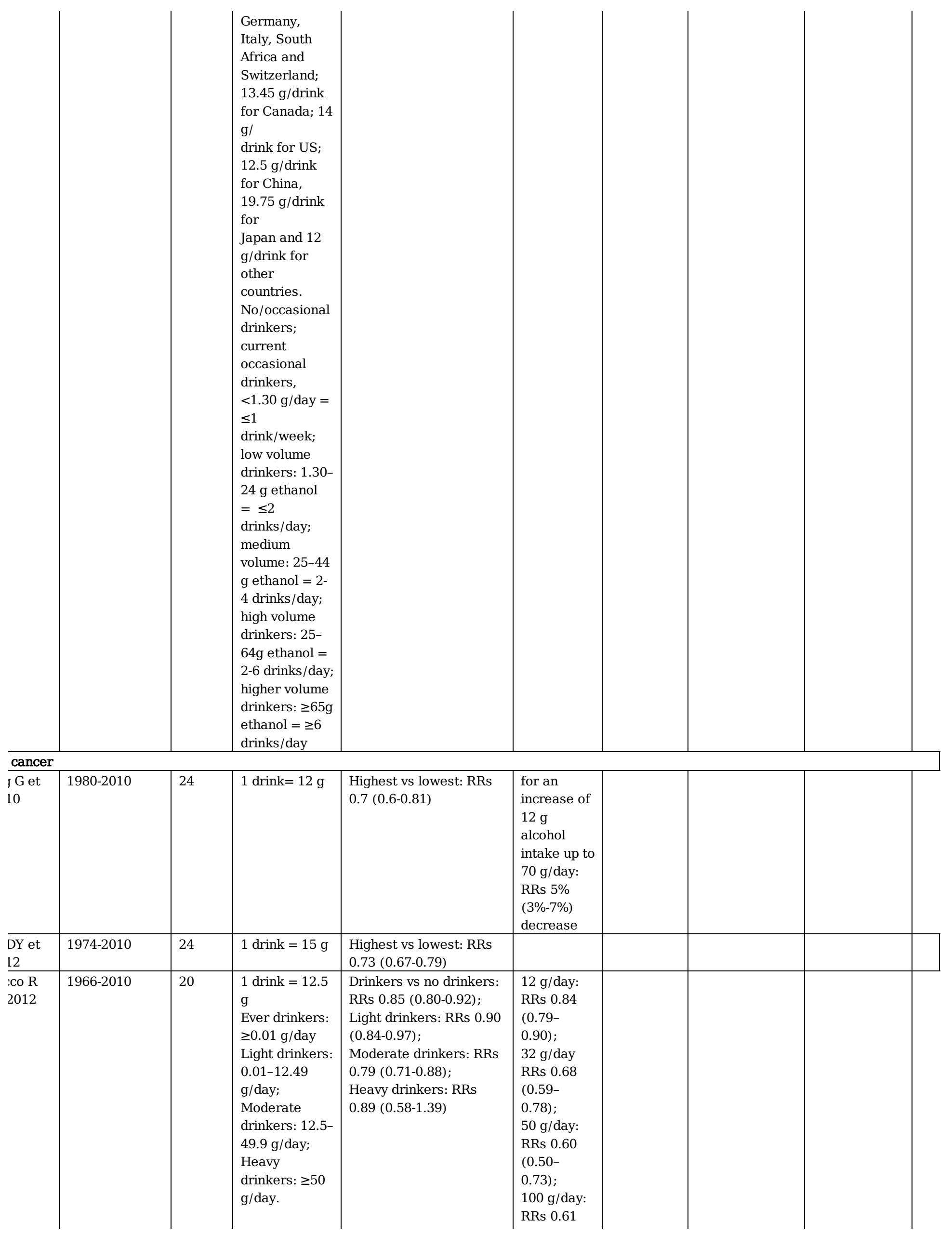




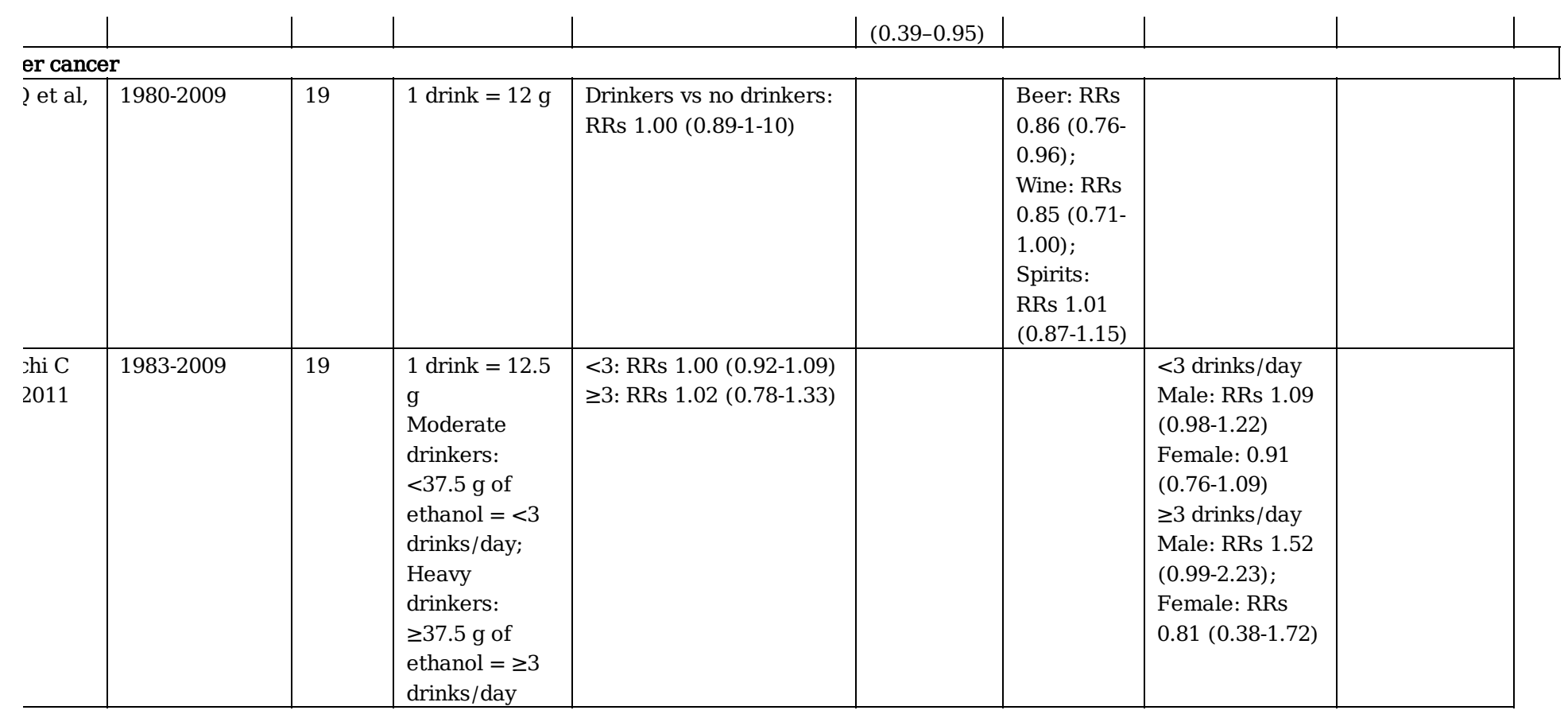

Table 1:characteristics of the study included in the review. 